\title{
Characteristics of four alkaline biosolids produced from sewage sludge
}

\author{
Ping-Chin Hsiau *, Shang-Lien Lo \\ Graduate Institute of Environmental Engineering, National Taiwan University, 71, Chou-Shan Road, \\ Taipei, Taiwan, ROC
}

Received 27 March 1997; received in revised form 1 September 1997; accepted 8 September 1997

\begin{abstract}
Four alkaline biosolids were produced from sewage sludge using lime, lime/sodium silicate, cement and cement/sodium silicate. X-ray diffractometry (XRD), scanning electron microscopy (SEM), energy dispersive X-ray analysis (EDAX), single chemical extraction and sequential extraction were used to determine the characteristics of alkaline biosolids and untreated sewage sludge. The results of extraction tests revealed that the percentages of organically-bound metals in untreated sewage sludge were in the order of $\mathrm{Cu}>\mathrm{Pb}>\mathrm{Cr}>$ $\mathrm{Zn}$. The percentages of exchangeable metals in four alkaline biosolids were also in this order, implying that the higher the affinity of heavy metals to organics in untreated sludge, the more unstable the heavy metals were in alkaline biosolids. This effect was attributed to the irreversible dissolution of organically-bound metals at very high $\mathrm{pH}$ during processing and air drying of sludge. Sodium silicate addition promoted alkaline biosolids drying due to the formation of silica/silicate gels which held free water in sludges. The alkaline biosolids had relatively high $\mathrm{CaCO}_{3}$ equivalencies, ranging from 32.6 to $42.1 \%$ and may serve as potential liming amendments for acid soils. The $\mathrm{CaCO}_{3}$ peaks $\left(29.46^{\circ} 2 \theta\right)$ in XRD graphs for alkaline biosolids indicate the occurrence of carbonation, especially for lime/sodium silicate- and cement/sodium silicate-treated biosolids. The porousness of lime/sodium silicate-treated biosolids as shown in the SEM micrograph corresponds to its smaller density $(0.58 \mathrm{~g} / \mathrm{ml})$, compared to lime-treated biosolids. The micrograph of cement/sodium silicate-treated biosolids shows the absence of needle-like ettringite which commonly appears in Portland cement hydration. (C) 1997 Elsevier Science B.V.
\end{abstract}

\footnotetext{
* Corresponding author.
} 
Keywords: Biosolids; Cement; Lime; Sewage sludge; Sodium silicate

\section{Introduction}

In Taiwan, the quantities of sludges originating from municipal and industrial wastewater treatment plants are estimated to be $2.9 \times 10^{7}$ and $7.3 \times 10^{7} \mathrm{~m}^{3} /$ year, respectively [1]. The majority of sludge in Taiwan is disposed of in landfills, but this method of disposal may soon be ruled out by legislation. Therefore, the objective of the existing and emerging sludge treatment technologies focuses on waste reuse and resource recovery.

Alkaline biosolids originate from treatment of sewage sludge with alkaline materials to kill pathogens [2]. They often have relatively high $\mathrm{CaCO}_{3}$ equivalencies (CCE) and may serve as potential liming amendments in acid soils. Three commonly produced biosolids are lime-stabilized sewage sludge, cement/sodium silicatefixed sewage sludge and N-Viro Soil [3]. Lime-stabilized sewage sludge is produced when lime is used to raise the sewage sludge $\mathrm{pH}$ to 12 [4,5]. Cement/sodium silicate-fixed sewage sludge is a product of the Chemfix process, which uses Portland cement and a sodium silicate as setting agents [6-8]. Alkaline cement kiln dust and lime kiln dust are used to raise the sewage sludge $\mathrm{pH}$ and produce N-Viro Soil $[2,6,8]$. Little information is available on alkaline biosolids microstructures, microscopic spatial distribution of chemical elements and especially fractionation and leachability of heavy metals. The purpose of this study was to evaluate these characteristics of untreated sewage sludge and four alkaline biosolids produced from sewage sludge by bench processes. X-ray diffractometry (XRD), scanning electron microscopy (SEM), energy dispersive X-ray analysis (EDAX), single extraction and sequential extraction were used for the above purpose. Lime, lime/sodium silicate, cement and cement/sodium silicate were used as treatment additives for processing the four alkaline biosolids.

\section{Methods}

The materials used in this study were sodium silicate (Merck; $\mathrm{Na}_{2} \mathrm{O}=7.5-8.5 \%$; $\mathrm{SiO}_{2}=25.5-28.5 \%$; density $=1.296-1.396 \mathrm{~g} / \mathrm{ml} ; 11=1.37 \mathrm{~kg}$; water content $=$ $62 \%$ ), sewage sludge cake (aerobically digested sludge sampled from the filter press outlet of the Min-Sheng Wastewater Treatment Plant, Taipei; water content = $86.4 \%$ ), lime (reagent grade $\mathrm{Ca}(\mathrm{OH})_{2}$ ) and Portland cement (type I). Four alkaline biosolids were prepared: lime-treated, lime/sodium silicate-treated, cement-treated and cement/sodium silicate-treated biosolids. Lime/sodium silicate- and cement/ sodium silicate-treated biosolids were prepared in three steps: manual mixing of the sludge with sodium silicate, further mixing (also manual) with added lime or cement and curing by air drying. Lime- and cement-treated biosolids were prepared by 
Table 1

Compositions of biosolids and untreated sewage sludge

\begin{tabular}{llccc}
\hline Samples & Composition & & \\
\cline { 2 - 5 } & Sewage sludge cake $(\mathrm{g})$ & Sodium silicate $(\mathrm{ml})$ & $\mathrm{Ca}(\mathrm{OH})_{2}(\mathrm{~g})$ & Cement $(\mathrm{g})$ \\
\hline $\mathrm{LB}^{\mathrm{b}}$ & 200 & 0 & 20 & 0 \\
$\mathrm{LSB}^{\mathrm{b}}$ & 200 & 15 & 20 & 0 \\
$\mathrm{CB}^{\mathrm{b}}$ & 200 & 0 & 0 & 25 \\
$\mathrm{CSB}^{\mathrm{b}}$ & 200 & 10 & 0 & 25 \\
$\mathrm{~S}^{\mathrm{c}}$ & 500 & 0 & 0 & 0 \\
\hline
\end{tabular}

LB, lime-treated biosolids; LSB, lime/sodium silicate-treated biosolids; CB, cement-treated biosolids; CSB, cement/sodium silicate-treated biosolids; S, untreated sewage sludge.

a $86.4 \%$ water.

${ }^{\mathrm{b}}$ Air-dried, $20-25^{\circ} \mathrm{C}$.

${ }^{\mathrm{c}}$ Oven-dried, $60^{\circ} \mathrm{C}$.

manual mixing of sludge with lime and cement, respectively, followed by air drying. Untreated sludge was prepared by oven drying $\left(60^{\circ} \mathrm{C}\right)$ of sewage sludge cake. The composition of each sample was listed in Table 1. Final products from the above treatment were stored in PVC bottles.

Single extraction tests, including extraction with distilled water, $0.1 \mathrm{M} \mathrm{MgCl}_{2}$ and $0.1 \mathrm{M}$ HAc solutions were carried out in $50 \mathrm{ml}$ centrifuge tubes shaken in a reciprocal shaker bath (Yihder BT350R) at $125 \mathrm{rpm}, 25^{\circ} \mathrm{C}$. Each tube contained 1 $\mathrm{g}$ of sieved sample ( $80 \mathrm{mesh})$ diluted to $40 \mathrm{ml}$ with extraction solution. Each extraction lasted for $24 \mathrm{~h}$, after which the supernatant from the centrifugation (Kubota 6800) at $12000 \times g$ for 10 min was decanted, then analyzed with an atomic adsorption spectrometer (Perkin Elmer 4000) and a total organic carbon analyzer (O - I Corporation 700) for concentrations of heavy metals and dissolved organic carbon (DOC). The residues from the centrifugation were discarded. In addition, for performing the extraction with the distilled water adjusted to various $\mathrm{pH}$ (1-13), a fixed amount of $1 \mathrm{M} \mathrm{NaOH}$ or $1 \mathrm{M} \mathrm{HCl}$ was added to the tube prior to full dilution of each sample to $40 \mathrm{ml}$. $\mathrm{pH}$ was measured at the end of each extraction.

Table 2

Procedure of sequential extraction

\begin{tabular}{ll}
\hline Step fraction & Extraction \\
\hline Exchangeable & $1 \mathrm{~mol} / 1 \mathrm{MgCl}_{2}(\mathrm{pH} 7), 20^{\circ} \mathrm{C}$ \\
Carbonate-bound & $1 \mathrm{~mol} / 1 \mathrm{NaOAc}+\mathrm{HOAc}(\mathrm{pH} 5), 20^{\circ} \mathrm{C}$ \\
Oxide bound & $0.04 \mathrm{~mol} / 1 \mathrm{NH}_{2} \mathrm{OH} \cdot \mathrm{HCL}+25 \% \mathrm{HOAc}, 95^{\circ} \mathrm{C}$ \\
Organically-bound & $30 \% \mathrm{H}_{2} \mathrm{O}_{2}+0.02 \mathrm{~mol} / 1 \mathrm{HNO}(\mathrm{pH} 2), 85^{\circ} \mathrm{C} ; 2 \mathrm{~mol} / 1 \mathrm{NH}_{4} \mathrm{OAc}+20 \% \mathrm{HNO}_{3}$ \\
Residual & $\mathrm{HF} / \mathrm{HClO}_{4}$ \\
\hline
\end{tabular}


To fractionate heavy metals in alkaline biosolids and untreated sewage sludge, Tessier's method of sequential extraction was performed (Table 2). Heavy metals in each sample were fractionated into exchangeable, carbonate, oxide-bound, organically-bound and residual forms $[9,10]$.

X-ray diffractometry was performed with powdered samples. XRD patterns were obtained with a X-ray diffractometer (Shimadzu, XD-5) using $\mathrm{CuK} \alpha$ radiation. The operation conditions for the X-ray examinations were the following: $45 \mathrm{KeV}$ accelerating voltage, $35 \mathrm{~mA}$ current, $10-70^{\circ} 2 \theta$ scanning range, $0.02^{\circ}$ step-width and $4^{\circ} /$ min scanning speed.

An EDAX International Model ECON-149-10 energy dispersive x-ray analyzer unit equipped with an EDAX 9100 computer mounted on a HITACHI S-2400 scanning electron microscope was utilized in the study. The SEM was operated at $15 \mathrm{KeV}$ acceleration voltage with a $150 \mu \mathrm{A}$ filament current. Samples were powdered prior to analysis and spectra were collected for a 2500-8000 count $\mathrm{Ca}$ or Si peak.

Sample $\mathrm{pH}$ was determined in a 1:10 sample: $0.01 \mathrm{M} \mathrm{CaCl}_{2}$ solution. Calcium carbonate equivalence (CCE) was determined by boiling the biosolids in $0.5 \mathrm{M} \mathrm{HCl}$ and back-titrating the excess $\mathrm{HCl}$ with standardized $0.25 \mathrm{M} \mathrm{NaOH}$ [11].

\section{Results and discussion}

\subsection{Basic characteristics of biosolids}

The $\mathrm{pH}$ of the samples, from the most to the least alkaline, was in the order of lime-treated biosolids $>$ lime/sodium silicate-treated biosolids $>$ cement-treated biosolids $>$ cement/sodium silicate-treated biosolids $>$ untreated sewage sludge (Table 3). Compared to lime-treated biosolids, the $\mathrm{pH}$ drop of lime/sodium silicate-treated biosolids was due to the incorporation of $\mathrm{Ca}(\mathrm{OH})_{2}$ by silicate gels without the liberation of equivalent $\mathrm{NaOH}$. This is supported by the report of Kalousek [12] who concluded that the reaction between sodium silicate and lime can form $\mathrm{Na}_{2} \mathrm{O}-\mathrm{CaO}-\mathrm{SiO}_{2}-\mathrm{H}_{2} \mathrm{O}$ gel.

The amounts of heavy metals in the sewage sludge from Min-Sheng Wastewater Treatment Plant, Taipei was not high (Table 3), meeting the requirements for land application (USEPA Part 503 Regulations). The percentages of heavy metals in lime-treated biosolids was about one-half those in untreated sewage sludge, resulting from the diluting effect of lime added to the sludge. On the other hand, Portland cement and sodium silicate both inherently contained heavy metals; thus, the amounts of heavy metals in lime/sodium silicate-treated, cement-treated and cement/sodium silicate-treated biosolids were higher than those in lime-treated biosolids. Since the amount of combined water and the weight of biosolids varied after treatment, the mass balance of heavy metals was difficult to calculate.

Alkaline biosolids had relatively high $\mathrm{CaCO}_{3}$ equivalencies, ranging from 32.6 to $42.1 \%$ (Table 3 ) and may serve as potential liming amendments for acid soils. Table 3 shows that the addition of sodium silicate increased moisture content in alkaline 
Table 3

Basic characteristics of alkaline biosolids and untreated sewage sludge (by average)

\begin{tabular}{llllll}
\hline Parameter & LB $^{\mathrm{a}}$ & LSB $^{\mathrm{a}}$ & CB $^{\mathrm{a}}$ & CSB $^{\mathrm{a}}$ & $\mathrm{S}^{\mathrm{b}}$ \\
\hline $\mathrm{pH}$ & 12.05 & 11.82 & 10.78 & 10.64 & 7.65 \\
Water $(\%)$ & 7.0 & 14.9 & 11.0 & 10.8 & 0 \\
Bulk density $(\mathrm{g} / \mathrm{ml})^{\mathrm{c}}$ & 0.70 & 0.58 & 0.65 & 0.42 & 0.62 \\
$\mathrm{VS}(\%)$ & 33.2 & 37.0 & 37.2 & 32.6 & 62.2 \\
$\mathrm{C}(\%)$ & - & - & - & - & 43.2 \\
Total-N (g/kg) & 302 & 319 & 315 & 310 & 892 \\
$\mathrm{CCE}(\%)$ & 42.1 & 36.5 & 33.1 & 32.6 & 0 \\
$\mathrm{Cr}(\mathrm{mg} / \mathrm{kg})$ & 52.2 & 63.0 & 73.4 & 86.3 & 89.9 \\
$\mathrm{~Pb}(\mathrm{mg} / \mathrm{kg})$ & 97.1 & 82.3 & 93.98 & 85.6 & 152.4 \\
$\mathrm{Zn}(\mathrm{mg} / \mathrm{kg})$ & 621.5 & 517.5 & 625.2 & 498.9 & 1089 \\
$\mathrm{Cu}(\mathrm{mg} / \mathrm{kg})$ & 119.4 & 96.1 & 112.0 & 96.9 & 202.0 \\
\hline
\end{tabular}

For abbreviations see Table 1 .

Sodium silicate solution and cement inherently contained heavy metals and both the weight and combined water content of the products varied after treatment; therefore, mass balance was not calculated.

${ }^{\mathrm{a}}$ Air-dried, $20-25^{\circ} \mathrm{C}$.

${ }^{\mathrm{b}}$ Oven-dried, $60^{\circ} \mathrm{C}$.

c80-mesh samples.

biosolids; visual observations revealed that the addition of sodium silicate promoted sludge drying. These were due to the formation of silica/silicate gels, which have the ability to hold all of the system water in sewage sludge as reported by Conner [13]. The bulk densities of lime/sodium silicate- and cement/sodium silicatetreated biosolids were lower than those of lime- and cement-treated biosolids (80-mesh sieved samples), respectively (Table 3). It was thought to result from the addition of sodium silicate.

\subsection{Scanning photomicrographs of biosolids}

SEM analysis revealed the differences in the gross microstructure between alkaline biosolids and untreated sewage sludge. The SEM micrograph of untreated sewage sludge shows the presence of silk-like material at the edge of the particle (Fig. 1a). The silk-like material may be residual material from biota. The micrograph of lime-treated biosolids shows that calcium hydroxides fill up empty spaces in sewage sludge (Fig. 1b), corresponding to $\mathrm{Ca}(\mathrm{OH})_{2}$ peaks in the XRD graph for lime-treated biosolids (Fig. 3b). The micrograph of lime/sodium silicatetreated biosolids shows the absence of calcium hydroxides (Fig. 1c). The appearance of gel-like particles in Fig. 1c indicates the formation of silica/silicate gel. The relatively larger pore diameter of lime/sodium silicate-treated biosolids in Fig. 1c corresponds to its smaller density $(0.58 \mathrm{~g} / \mathrm{ml})$, compared to lime-treated biosolids (Table 3). Cote [14] reported a similar effect of sodium silicate on porosity increase, which may lead to enhanced carbonation of biosolids via increased contact area with air, as will be discussed later. The micrograph of cement-treated biosolids 
shows the presence of needle-like ettringite which commonly appears in Portand cement hydration (Fig. 1d), meaning that sewage sludge acts as a retarder in the setting of cement. The micrograph of cement/sodium silicate-treated biosolids shows the absence of needle-like ettringite (Fig. 1e).

(a) Untreated sewage sludge

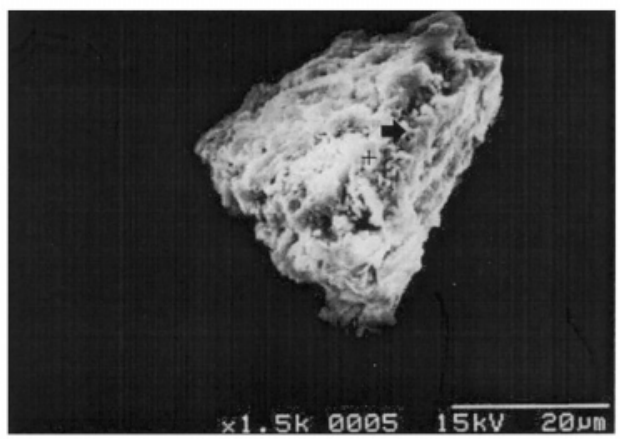

(c) Lime/sodium silicate-treated biosolids

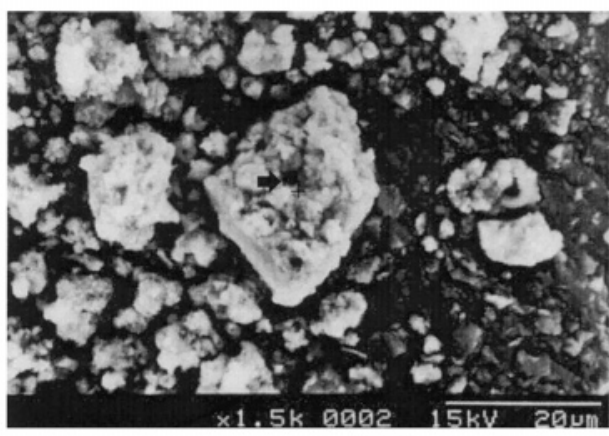

(e) Cement/sodium silicate-treated biosolids

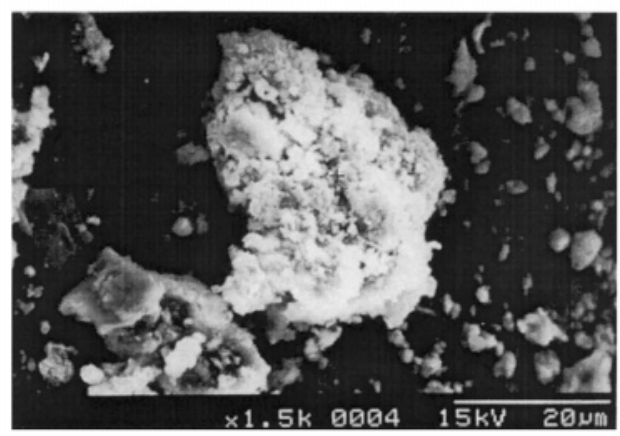

Fig. 1. Scanning photomicrographs of powdered biosolids (80-mesh). The spots labeled '+' correspond to EDAX analysis. (b) Lime-treated biosolids

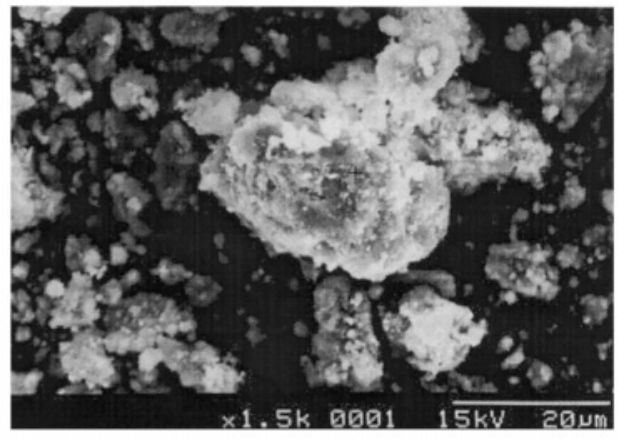

(d) Cement-treated biosolids

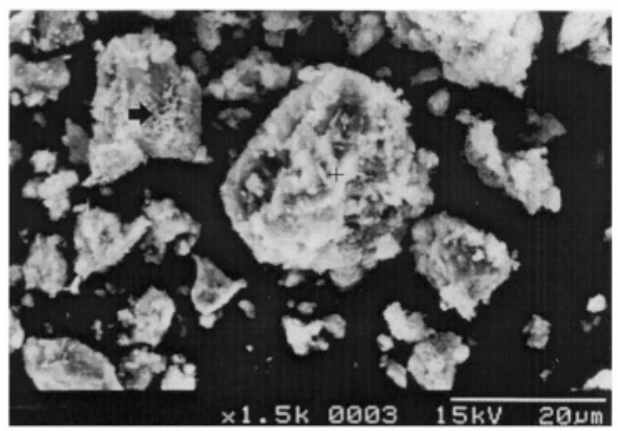




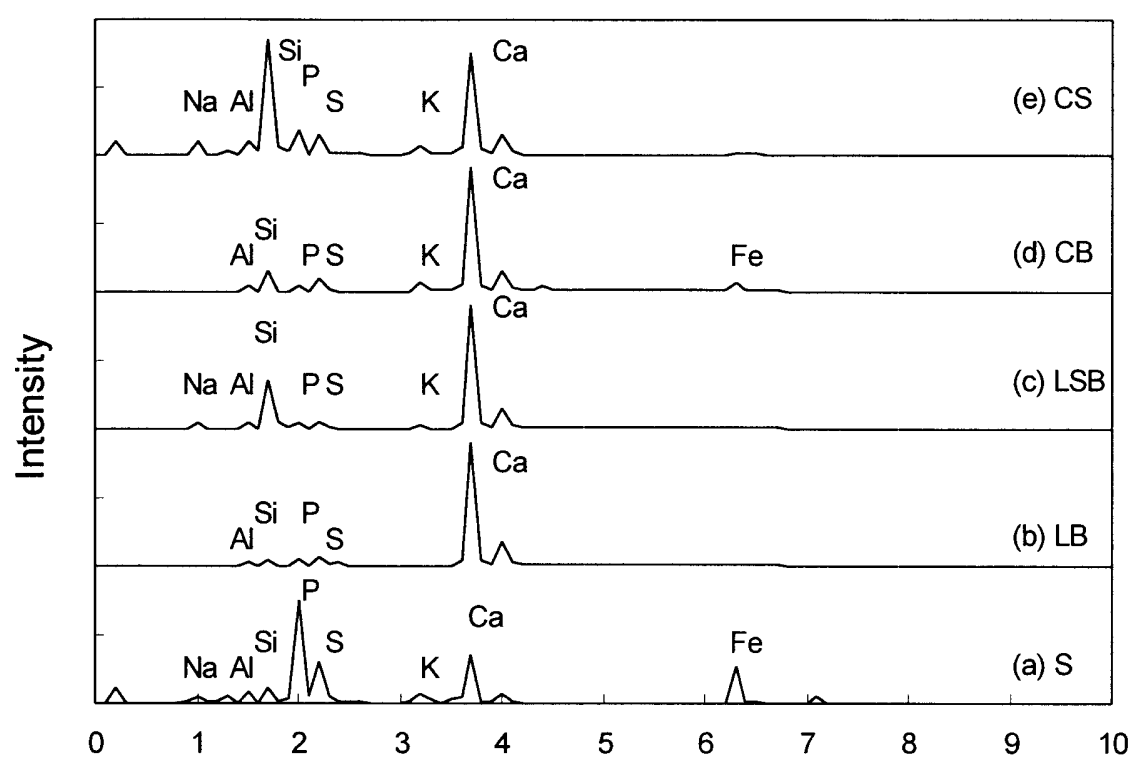

Fig. 2. X-ray spectra of biosolids: (a) S, untreated sewage sludge; (b) LB, lime-treated biosolids; (c) LSB, lime/sodium silicate-treated biosolids; (d) CB, cement-treated biosolids; and (e) CSB, cement/sodium silicate-treated biosolids.

\subsection{EDAX analysis of biosolids}

$\mathrm{Na}, \mathrm{Al}, \mathrm{Si}, \mathrm{P}, \mathrm{S}, \mathrm{K}, \mathrm{Ca}$ and $\mathrm{Fe}$ were all detectable in X-ray spectra analysis for untreated sewage sludge (Fig. 2a). The increased peak intensity of Ca for alkaline biosolids was due to the addition of lime and cement (Fig. 2b-e). The increased peak intensity of Si for lime/sodium silicate-treated, cement-treated and cement/ sodium silicate-treated biosolids was due to the addition of cement and sodium silicate (Fig. 2c and 2e). The reduced peak intensities of $\mathrm{Na}, \mathrm{P}, \mathrm{S}, \mathrm{K}$ and $\mathrm{Fe}$ for alkaline biosolids were due to the diluting effect of additives which reduce the relative concentration of components inherently existing in sewage sludge (Fig. $2 b-e)$.

\subsection{XRD patterns of biosolids}

The XRD patterns show that quartz $\left(26.90^{\circ} 2 \theta\right)$ formed the main mineral component in untreated sewage sludge (Fig. 3a). Chemical treatment of sludge for producing alkaline biosolids reduced the peak intensity of quartz, resulting from the diluting effect of additives which reduced the relative amount of inert matter (e.g. quartz) in alkaline biosolids. The appearance of $\mathrm{Ca}(\mathrm{OH})_{2}$ at various degrees for lime-treated biosolids (Fig. 3b) and of $\mathrm{C}_{3} \mathrm{~S}$ for cement-treated biosolids (Fig. 3d) indicated that lime and cement were not exhausted during the treatment. The addition of sodium silicate, on the other hand, allowed $\mathrm{Ca}(\mathrm{OH})_{2}$ and $\mathrm{C}_{3} \mathrm{~S}$ to be 
incorporated, as evidenced by the absence of these peaks in XRD graphs for lime/ and cement/sodium silicate-treated biosolids (Fig. 3c and 3e). The products of $\mathrm{Ca}(\mathrm{OH})_{2}$ and $\mathrm{C}_{3} \mathrm{~S}$ incorporation by silicate were noncrystalline and therefore, difficult to characterize structurally by XRD. Other investigators $[13,15,16]$ have mentioned that sodium silicate contains both polymeric silicates and colloidal silica which can interact with divalent calcium to form silica/silicate gels. Kalousek [12] reported that the reaction between lime, sodium and water formed $\mathrm{Na}_{2} \mathrm{O}-\mathrm{CaO}-$ $\mathrm{H}_{2} \mathrm{O}-\mathrm{SiO}_{2}$ gel.

The $\mathrm{CaCO}_{3}$ peaks $\left(29.46^{\circ} 2 \theta\right)$ in the XRD graphs for alkaline biosolids indicated the occurrence of carbonation (Fig. 3). These peaks were much more enhanced for lime/ and cement/sodium silicate-treated biosolids, compared to lime- and cementtreated biosolids, indicating that sodium silicate addition resulted in further carbonation. $\mathrm{CaCO}_{3}$ can be formed through the carbonation of hydrated lime or cement hydrate gel in the presence of air. The enhanced carbonation of lime/ and cement/sodium silicate-treated biosolids was due to their porous nature, which increased the surface contact area with air. Water was observed on the surface of lime/ and cement/sodium silicate-treated biosolids during curing. It was also thought to result from carbonation: $\mathrm{Ca}(\mathrm{OH})_{2}+\mathrm{CO}_{2} \rightarrow \mathrm{CaCO}_{3}+\mathrm{H}_{2} \mathrm{O} ; \Delta H_{i}=-69$ $\mathrm{KJ} / \mathrm{mol}$.

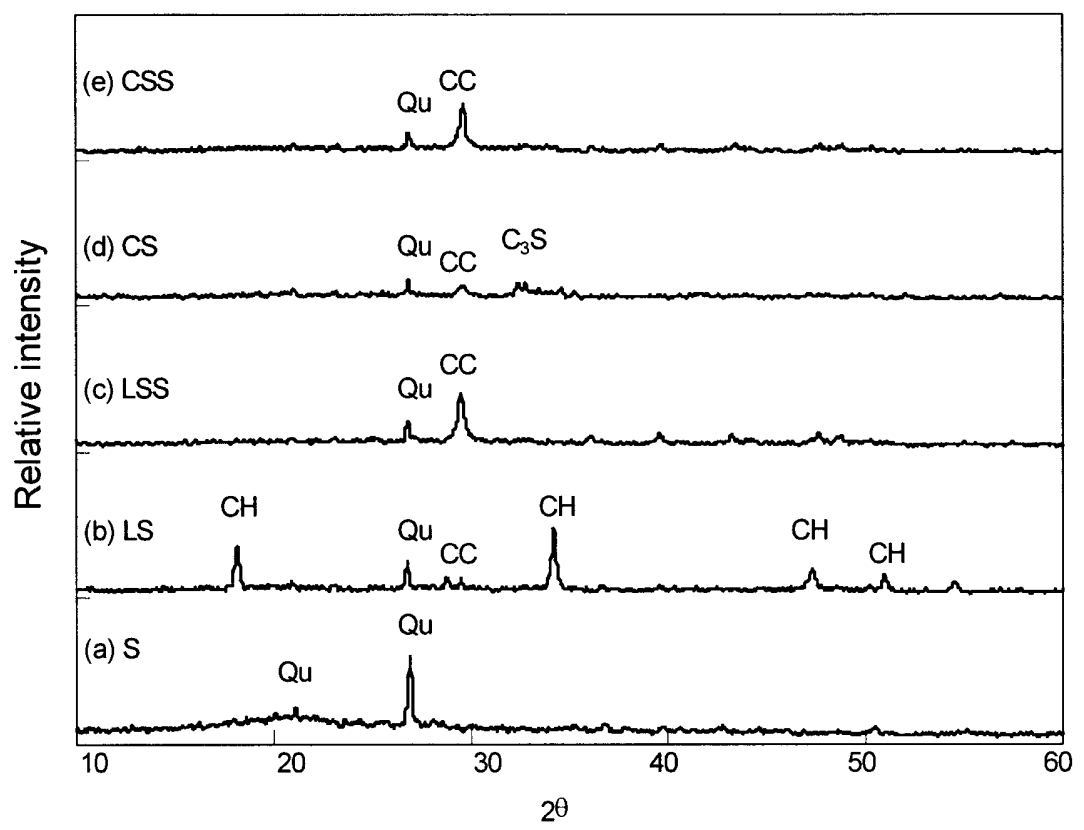

Fig. 3. XRD patterns of Biosolids. (a) S, untreated sewage sludge; (b) LB, lime-treated biosolids; (c) LSB, lime/sodium silicate-treated biosolids; (d) CB, cement-treated biosolids; and (e) CSB, cement/ sodium silicate-treated biosolids. ${ }^{*} \mathrm{C}_{3} \mathrm{~S}$, tricalcium silicate $\left(3 \mathrm{CaO} \cdot \mathrm{SiO}_{2}\right) ; \mathrm{CH}$, calcium hydrate; $\mathrm{CC}$, calcium carbonate; $\mathrm{Qu}$, Quartz $\left(\mathrm{SiO}_{2}\right)$. 


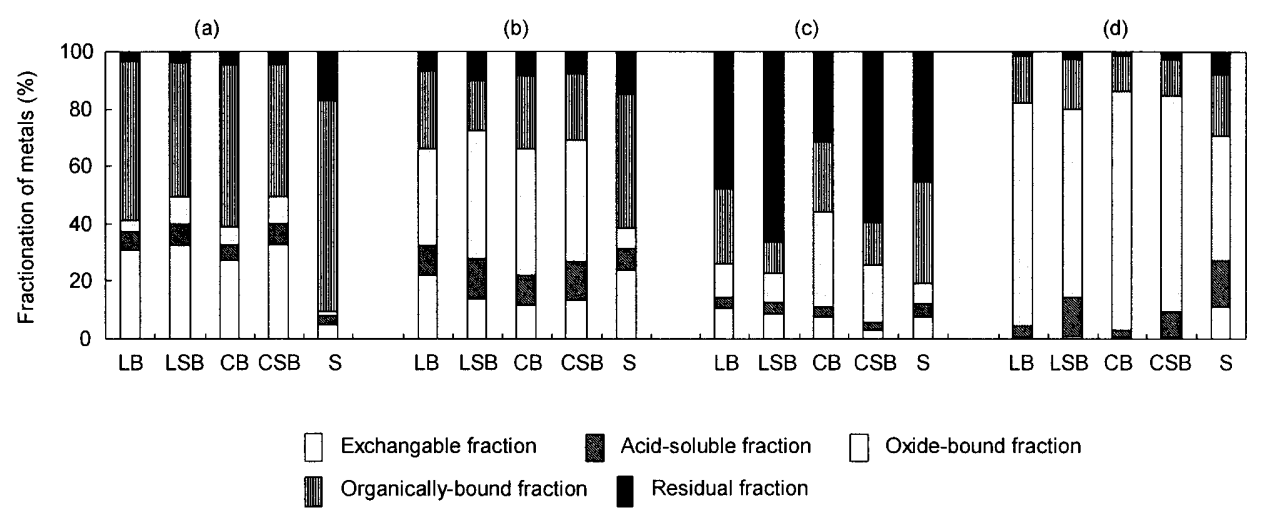

Fig. 4. Fractionation of (a) $\mathrm{Cu}$; (b) $\mathrm{Pb}$; (c) $\mathrm{Cr}$; and (d) $\mathrm{Zn}$ in biosolids. * $\mathrm{S}$, untreated sewage sludge; LB, lime-treated biosolids; LSB, lime/sodium silicate-treated biosolids; CB, cement-treated biosolids; CSB, cement/sodium silicate-treated biosolids.

\subsection{Sequential extraction}

Sequential extraction indicated that the amounts of $\mathrm{Zn}, \mathrm{Cu}$ and $\mathrm{Pb}$ of carbonate form in lime/ and cement/sodium silicate-treated biosolids were greater than those in lime- and the cement-treated biosolids, respectively (Fig. 4a, b and d). This corresponds to the enhanced carbonation in lime/ and cement/sodium silicatetreated biosolids, concluded in the XRD observation.

The percentages of $\mathrm{Pb}, \mathrm{Cu}, \mathrm{Zn}$ and $\mathrm{Cr}$ in the organically-bound form in alkaline biosolids were consistently lower than those in untreated sewage sludge (Fig. $4 a-d$ ). This was thought to be due to the irreversible dissolution of organically-bound heavy metals at very high $\mathrm{pH}$ during processing and air drying of alkaline biosolids. After processing and air drying of the biosolids, $\mathrm{Cu}$ shifted from organically-bound to exchangeable (Fig. 4a), $\mathrm{Pb}$ to oxide-bound (Fig. 4b) and $\mathrm{Cr}$ to residual (lime/ and cement/sodium silicate-treated biosolids) or oxide-bound fraction (lime- or cement-treated biosolids; Fig. 4c). However, the shift of $\mathrm{Zn}$ was not obvious, since little $\mathrm{Zn}$ existed in the organically-bound form in untreated sewage sludge $(21.4 \%$; Fig. 4d)

The addition of sodium silicate led to the shift of $\mathrm{Cu}, \mathrm{Pb}$ and $\mathrm{Cr}$ from the organically-bound fraction to other fractions when comparing lime/sodium silicate (cement/sodium silicate)-treated biosolids with lime (cement)-treated biosolids (Fig. $4 \mathrm{a}-\mathrm{d})$. It was assumed that the shift was due to the competition between silica/silicate gel and organics for metal ions. According to Bishop [17], $\mathrm{Cr}$ and $\mathrm{Pb}$ can be bound into the silica matrix and become resistant to leaching.

The fractionation of $\mathrm{Cr}$ was most unique in this investigation. The addition of sodium silicate led to the shift of $\mathrm{Cr}$ from organically-bound to residual fraction (Fig. 1c). Sequential extraction indicated that the majority of $\mathrm{Si}(>90 \%)$ was distributed in residual fraction (not presented schematically) as reported by Tessier (1979), suggesting that the shifted $\mathrm{Cr}$ was bound into silicate. Cocke et al. [18] 
concluded that $\mathrm{Cr}$ in cement-based systems was different from other metals for its size and charge, which allowed it to be incorporated throughout the solid material during hydration. Bishop [17] reported that $\mathrm{Cr}$ was bound into the silica matrix. Mollah et al. [19] reported that $\mathrm{Cr}$ ions substituted for silicon in $\mathrm{C}-\mathrm{H}-\mathrm{S}$ gel and the leaching process by acetic buffer ( $\mathrm{pH} 4.85$ ) did not significantly change either $\mathrm{Si}$ or $\mathrm{Cr}$.

\subsection{Single extraction}

The amounts of heavy metals in the organically-bound form in untreated sewage sludge strongly influenced the extraction of heavy metals from alkaline biosolids. In terms of organically-bound metal distribution in untreated sewage sludge, $\mathrm{Cu}$ was present in the the highest quantity $(73.7 \%)$ and $\mathrm{Zn}$ in the lowest $(21.4 \%)$, while $\mathrm{Pb}$ and $\mathrm{Cr}$ were in-between (46.6 and 35.2\%, respectively). We found that the amounts of heavy metals of exchangeable form in alkaline biosolids depended on the amounts of heavy metals of organically-bound form in untreated sewage sludge, irrespective of metal species (Fig. 5a). The percentages of heavy metals of organically-bound form in untreated sludge were in the order of $\mathrm{Cu}>\mathrm{Pb}>\mathrm{Cr}>\mathrm{Zn}$ (Tessier's method of sequential extraction was used). The percentages of heavy metals of exchangeable form in alkaline biosolids were also in this order. The relationship equation of regression was $E=0.59 \times(O R)-12.42 ; R^{2}=0.95 ; E$, percentage of exchangeable metal in alkaline biosolids, irrespective of types of treatment process; $O R$, percentage of organically-bound metal in untreated sludge, irrespective of metal species. According to the above equation, the higher the percentages of heavy metals of organically-bound form in untreated sewage sludge, the more unstable the heavy metals were in alkaline biosolids, since heavy metals of exchangeable form were the most labile. This effect was suggested to be due to the irreversible dissolution of organics and organically-bound metals at very high $\mathrm{pH}$ during processing and air drying of the sludge. After processing and air drying of the sludge, the derived precipitants of dissolved organics and organically-bound metals became exchangeable. Single extraction also indicated that the extractability of heavy metals in alkaline biosolids depended on the amounts of metals of organically-bound form in untreated sewage sludge (Fig. 5b-c). This also illustrated that some heavy metals (e.g. $\mathrm{Cu}$ ) became more unstable in the sludge after treatment, due to their affinity for organics. In contrast, the metals (e.g. $\mathrm{Zn}$ ) having less affinity for organics became stable after sludge treatment. Conner [13] stated that the cement-based immobilization process of organic wastes can increase heavy metal leaching if the $\mathrm{pH}$ of the process exceeds the normal range. The data of Sims [20] showed an increasing uptake of $\mathrm{Cu}$ in plants, but a decreasing plant uptake of $\mathrm{Zn}$, with increased liming rate in the soils, amended with composted sewage sludge. Other authors have reported that liming increased the extractability of some metals $[21,22]$.

The organic content in alkaline biosolids was less than that in untreated sewage sludge, while the extraction concentration of DOC from alkaline biosolids was several times that from untreated sewage sludge (Fig. 5d). This was attributed to 
the irreversible dissolution of organics at very high $\mathrm{pH}$ during the processing and air drying of the biosolids. The conditions for processing and air drying the biosolids were similar to those for the extraction of untreated sewage sludge conducted at very high $\mathrm{pH}$ (Fig. 5d), leading to strong extraction concentrations of organics and organically-bound metals. Since the majority of $\mathrm{Cu}(73 \%)$ was in the organically-bound form in untreated sewage sludge, it was expected that $\mathrm{Cu}$ in alkaline biosolids would irreversibly dissolve with organics during the processing and air drying of the sludge. This is supported by the increased amount of

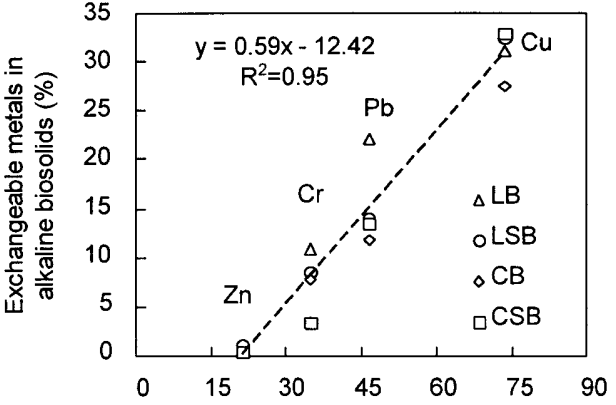

(a)

Organically-bound metals in untreated sludge (\%)

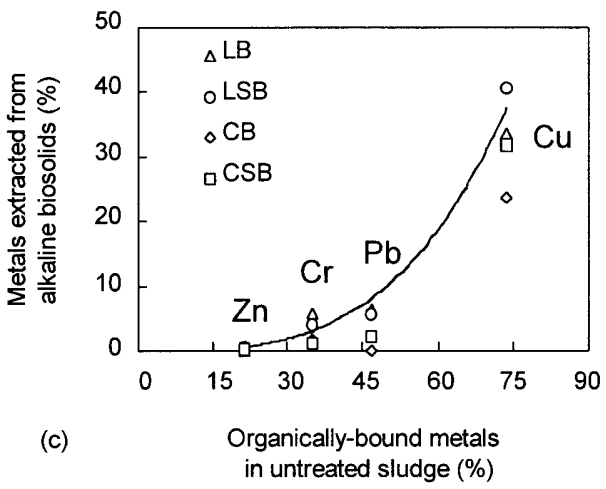

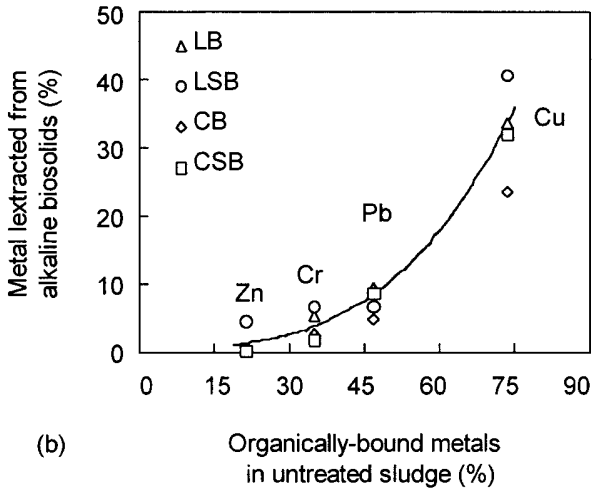

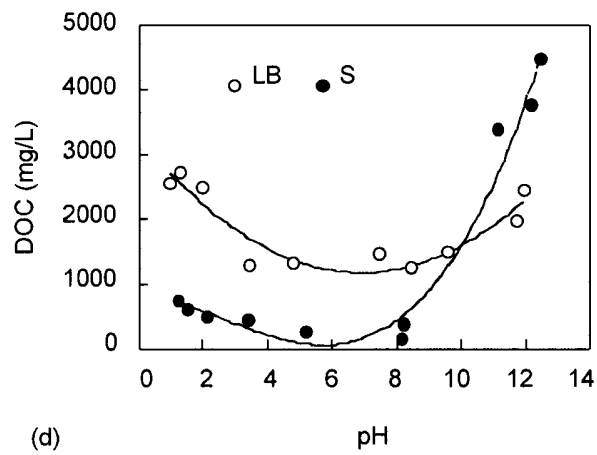

Fig. 5. Results of extraction. (a) Relationship between the percentage of exchangeable metals (sequential extraction) in four alkaline biosolids and the percentage of organically-bound metals (sequential extraction) in untreated sewage sludge, irrespective of metal species; (b) relationship between the percentage of metals extracted (single extraction with $0.01 \mathrm{M}$ HAc solutions) from four alkaline biosolids and the percentage of organically-bound metals (sequential extraction) in untreated sewage sludge; (c) relationship between the percentage of metals extracted (single extraction with $0.1 \mathrm{M} \mathrm{MgCl}_{2}$ solutions) from four alkaline biosolids and the percentage of organically-bound metals (sequential extraction) in untreated sewage sludge; and (d) extraction concentration of dissolved organic carbon (DOC; single extraction) vs $\mathrm{pH}$. * S, untreated sewage sludge; LB, lime-treated biosolids; LSB, lime/sodium silicate-treated biosolids; CB, cement-treated biosolids; CSB, cement/sodium silicate-treated biosolids. 
exchangeable $\mathrm{Cu}$ in alkaline biosolids, compared to untreated sewage sludge (Fig. $4 a)$.

\section{Conclusions}

This study has revealed that sodium silicate addition promotes the drying of alkaline biosolids due to the formation of silica/silicate gels that hold free water in sewage sludge. Alkaline biosolids had relatively high $\mathrm{CaCO}_{3}$ equivalencies, ranging from 32.6 to $42.1 \%$ and may serve as potential liming amendments for acid soils. The $\mathrm{CaCO}_{3}$ peaks $\left(29.46^{\circ} 2 \theta\right)$ shown in XRD graphs for alkaline biosolids indicated the occurrence of carbonation, especially for lime/ and cement/sodium silicate-treated biosolids. The porous appearance of lime/sodium silicate-treated biosolids in the micrograph corresponds to its relatively lower density $(0.58 \mathrm{~g} / \mathrm{ml})$, compared to lime-treated biosolids. The micrograph of cement/sodium silicatetreated biosolids shows the absence of needle-like ettringite which commonly appears in Portland cement hydration. The higher the affinity of heavy metals to organics, the more unstable were the metals in the sludge after treatment, explaining why the order of the heavy metals $(\mathrm{Cu}>\mathrm{Pb}>\mathrm{Cr}>\mathrm{Zn})$ of exchangeable form in alkaline biosolids was the same as that of the organically-bound form in untreated sewage sludge. This effect was attributed to the irreversible dissolution of organically-bound metals at very high $\mathrm{pH}$ during processing and air drying of the sludge. The processing and air drying conditions of biosolids were the same as the extraction conditions of untreated sewage sludge conducted at very high $\mathrm{pH}$, leading to strong extraction concentrations of organics and organically-bound metals.

\section{References}

[1] Lo KSL, Chen YH. Extracting heavy metals from municipal and industrial sludges. Sci Total Environ 1990;90:99-116.

[2] Sloan JJ, Basta NT. Remediation of acid soils by using alkaline biosolids. J Environ Qual 1995;24:1097-103.

[3] Logan TJ, Harrison BJ. Physical characteristics of alkaline stabilized sewage sludge and their effects on soil physical properties. J Environ Qual 1995;24:153-64.

[4] US Environmental Protection Agency. Process Design for Sludge Treatment and Disposal. USEPA, 625/1-79-011, Washington, DC: US Government Printing Office, 1979.

[5] US Environmental Protection Agency. Control of Pathogens and Vector Attraction in Sewage Sludge. USEPA, 625/R-92/013, Washington, DC: US Government Printing Office, 1992.

[6] Jacobs A, Silver M. Sludge management at the Middlesex County Utilities Authority. Water Sci Tech 1990;22:93-106.

[7] Trezek G.J. Polysilicate Heavy Metals Mitigation Technology, Physical Chemical Process. Pennsylvania: Technomic, 1990:155-162.

[8] Outwater A.B. Reuse of Sludge and Minor Wastewater Residuals. Boca Raton, Florida: CRC press, 1994:101-111.

[9] Tessier A, Campbell PGC, Bisson N. Sequential extraction procedure for the speciation of particulate trace metals. Anal Chem 1979;51:844-51. 
[10] Tack FMG, Verloo MG. Chemical speciation and fractionation in soil and sediment heavy metal analysis: a review. Int J Environ Anal Chem 1995;59:225-38.

[11] Rund R.C. Agricultural liming materials. In: Williams S., editor. Official Methods of Analysis of the Association of Official Analytical Chemists. Arlington, Virginia: AOAC, 1984:1.

[12] Kalousek G.L. J Res Natl Bur Stand 1944;32:285.

[13] Conner J.R. Chemical Fixation and Solidification of Hazardous Wastes. New York: Reinhold, 1990:376-406.

[14] Cote P. Contaminant Leaching From Cement-Based Waste Forms Under Acidic Conditions. Ph.D. thesis, McMaster University of Hamilton, Ontario, Canada, 1986.

[15] Vail J.G. Soluble Silicate. New York: Wiley, 1952.

[16] Gowman L.P. Chemical stability of metal silicates vs metal hydroxides in ground water conditions. In: Proceedings of the Second National Conference on Complete Water Reuse, Chicago, May 1975.

[17] Bishop PL. Leaching of inorganic hazardous constituents from stabilized/solidified hazardous wastes. Hazard Waste Hazard Mater 1988;5(2):129-43.

[18] Cocke DL, McWhinney HG, Dufner DC, Horrell B, Ortego JD. A surface investigation of Portland cement doped with $\mathrm{Pb}$ (II) and Cr (III) cations. Hazard Waste Hazard Mater 1989;6:25167.

[19] Mollah MYA, Tsai YN, Hess TR, Cocke DL. An FTIR, SEM and EDS investigation of solidification/stabilization of chromium using portland cement Type V and Type IP. J Hazard Mater 1992;30:273-83.

[20] Sims JT. Soil pH effects on the distribution and plant availability of mgnganese, copper and zinc. Soil Sci Soc Am J 1986;50:367-73.

[21] Bloomfield C, Pruden G. The effects of aerobic and anaerobic incubation on the extractabilities of heavy metals in digested sewage sludge. Environ Pollut 1975;8:217-32.

[22] Kelling KA, Keeney DR, Walsh LM, Ryan JA. A field study of the agricultural use of sewage sludge: III. Effect on uptake and extractability of sludge-borne metals. J Environ Qual 1977;6:3528. 